\title{
Public Private Partnership In China: Where To From Here
}

$\left|\begin{array}{l}\text { Yongjian Ke } \\ \text { School of Architecture and } \\ \text { Built Environment, } \\ \text { The University of } \\ \text { Newcastle, Callaghan, Australia } \\ \text { Yongjian.Ke@newcastle.edu.au }\end{array}\right|$

\begin{tabular}{|l|} 
Marcus Jefferies \\
School of Architecture and \\
Built Environment, \\
The University of Newcastle, \\
Callaghan, Australia \\
Marcus.Jefferies@newcastle.edu.au
\end{tabular}

\author{
Asheem Shrestha \\ Faculty of Architecture \\ Building and Planning, \\ The University of Melbourne, \\ Parkville, Australia; \\ asheemsh@hotmail.com
}

Xiao-Hua Jin
School of Computing,
Engineering and
Mathematics, The University
of Western Sydney,
Kingswood, Australia;
xiaohua.jin@uws.edu.au
DOI 10.5592/otmcj.2014.3.10

Literature Review

\section{Keywords}

Public Private Partnership, Infrastructure Development, China
The Chinese government has Shown an active attitude in ENCOURAGING AND SUPPORTING THE PARTICIPATION OF PRIVATE INVESTORS IN THE PROVISION OF PUBLIC INFRASTRUCTURE AND SERVICES. There is a huge investment opportunity for Public Private Partnership (PPP) in China. However, China has immature regulatory and institutional PPP frameworks. This paper hence aims to review the application of PPP in China and consequently draw lessons for future references. It was found that China has a wealth of experience with PPP under the strong support of central and subnational governments. Given the tremendous economic growth and immense demand for infrastructure, China will continue to have a massive demand for future PPP projects. This paper is important as its contribution is to summarize the application of PPP in China in terms of opportunities, current usage and future trends. 


\section{INTRODUCTION}

A Public-Private Partnership (PPP) is defined by The National Council for PPPs (2013) as a contractual agreement between a public agency and a private sector entity, through which each sector shares the skills, assets, risks and rewards in the delivery of a service and/or facility for the use of the general public. PPPs present a number of recognized advantages, such as private financing and project acceleration, integrated solution for public services, risk transfer to private sectors, life cycle efficiencies, etc. (Chan et al., 2009). Through this approach, private sector has been playing a significant role in the delivery of public infrastructure and services in many countries.

The continuous economic growth in China has resulted in an immense demand for infrastructures. To meet the development needs, the Chinese government has been proactive in promoting private involvement and investment in the infrastructure development. On the executive meeting of the State Council on July 312013 , Premier Keqiang Li stated that the government will continue to support the private investments and all investment entities will be treated equally. The central government also claimed to further widen the market access of public services to eligible private investors with sound credit. It can be expected that private investors would get more involved in infrastructure development via PPPs. However, China has often been criticized for having immature regulatory and institutional frameworks for PPP (Chan et al., 2010). Therefore, it is worth examining the PPP application in China, in order to derive lessons for future references.

This paper hence aims to review the PPP application in China. The review process was to: 1) examine the PPP opportunity; 2) examine the PPP environment; 3) examine the PPP usage; and 4) extrapolate the future developments of PPP. The sequence of the following sections is arranged as per the review process.

\section{PPP opportunity}

According to the China's 12th FiveYear Plan (2011-2015), China's annual average Gross Domestic Product (GDP) growth between 2006 and 2010 was $11.2 \%$, and the urbanization rate grew from $43 \%$ in 2005 to $47.5 \%$ in 2010 . In the 12th Five-Year Plan, China is expected to reach an annual average GDP growth of $7 \%$ and an urbanization rate of $51.5 \%$. In response to the rising urbanization, Chinese government is expected to continuously promote the development of public transportation to relieve traffic jams and enhance mobility for urban commuters. Other public facilities such as water supply, gas supply, and waste disposal are also in high demand to cope with the increasing urbanization. The 12th FiveYear Plan makes a turning point from previous emphasis on headline growth to strategies and measures for longterm prosperity. One of the important goals in these five years is to develop seven priority industries (i.e. new energy, energy conservation and environmental protection, biotechnology, new materials, new IT, high-end equipment manufacturing, and clean energy vehicles). The strategic objective of balanced development among regions and urbanization rate increase also creates massive infrastructure requirements.

It is thus understandable that the main drivers for adopting PPP in China are economy-related drivers. This is consistent with the findings of Chan et al. (2009) that the top drivers for PPP scored by Chinese respondents include: (1) to solve the problem of public sector budget restraint; (2) to provide an integrated solution (for public infrastructure/services); (3) to reduce public money tied up in capital investment; (4) to cap the final service costs; and (5) to reduce the total project cost. The emphasis on economy-related drivers for PPP in China is logical as China has a lot more investments and involvement in public projects. The government has realised that key targets set in the 12th
Five-Year Plan cannot be achieved if the government relies on public financing alone, especially given the truth that the central and subnational governments are suffering huge debts of RMB 123,841.04 Trillion (about US\$ 19,777.41 Trillion) and RMB 178,908.66 Trillion (about US\$ 28,571.71 Trillion) respectively (National Audit Office, 2013). Thus, the Chinese government is continuing to invite foreign companies and domestic private investors to participate in infrastructure development and public services.

\section{Environment for PPP}

Economist Intelligence Unit (EIU, 2012) summarized a benchmark index to assess the readiness and capacity of countries to carry out sustainable PPPs. This index comprises six components: 1) legal and regulatory framework for concession projects; 2 ) institutional framework (design and responsibilities of institutions that prepare, award and oversee projects); 3) operational maturity (number and success rate of past projects); 4) investment climate (business, political and social environment for investment); 5) financial facilities for funding infrastructure; and 6) subnational adjustment factor. According to EIU (2012), China scored 31.3, 25.0, $78.1,51.6,66.7$, and 75.0 out of 100 in these six components respectively. Unfortunately, the reasons behind the scores were not sufficiently discussed in EIU (2012). Therefore, this paper will adopt this six components index to examine the environment for PPP in China and provide more detailed discussions.

\section{Legal and Regulatory Framework}

Law and regulatory framework for PPP is immature and still evolving. EIU (2012) rated China 31.3 out of 100 on this component. Current PPP regulations are considered to lack a strong legal force in the forms of opinions, notices and decisions. They were issued by the State Council and its 
ministries, who only took into account their own responsibilities. As a result, these regulations lack completeness.

There are currently no mechanisms for value for money assessments or other decision making frameworks to ensure that PPP is the most appropriate option. Because of the immense budgetary pressure on the government to provide infrastructures, the concerns regarding efficiency in project procurement and delivery are often ignored. The decision to employ PPP is made in despite of the specific conditions of the target project. In addition, there is no formal process for deciding the type and extent of government support for PPPs. The government officials make decision based on their own judgments or preferences while the general public and even the professionals and academics have little or no influence on the decision-making (Sachs et al., 2007).

Although a feasibility study and post-evaluation for a PPP project are typically conducted, information relevant to appraisal, project details and post-implementation is usually not available to the general public. There is no obligation for the government or the investors to publish contracts and their amendments, which are usually regarded as commercial secrets (by investors) or official secrets (by governments).

However, there are several improvements in PPP related regulations in China. These improvements include switching PPP key players from foreigners solely to all private investors, widening PPP implementation from BOT only to diverse models, and providing more operational procedure guideline (Wang et al., 2012). More importantly, the PPP law was identified as one of the near future legislations at the 12th National People's Congress in March 2013. The setup of PPP law is led by the Department of Laws and Regulations of National Development and Reform Commission. The preparation work commenced in early 2014.
Institutional Framework

Among the six components, China scored the lowest (25.0 out of 100) in the component of institutional framework (EIU, 2012). This may be due to the fact that there are no national PPP-specific agencies in China. On May 26 2014, a PPP working group was established under the Ministry of Finance. However, the members of the working group are all its subordinates, while its role and responsibilities remain unclear.

PPP projects are treated in the same way as traditional state infrastructure projects. The State Council and its ministries, especially the Ministry of Housing and Urban-Rural Development (previously named Ministry of Construction), have issued several PPP regulations in the form of opinion, notice and decision. The National Development and Reform Commission and local planning commissions are in charge of evaluation and approval of project application reports of PPP projects. The Ministry of Housing and Urban-Rural Development is responsible for the overall administration of the tendering activities throughout the country, while the subnational construction authorities are responsible for those within their own areas. The main tasks of the subnational construction authorities are to prequalify private investors, review calling for tenders and tender documents, and supervise tender opening, tender evaluation and contract award.

There are usually two types of administrative arrangement for tender evaluation in PPP projects. The first form is to set up a separate tendering office, which is formulated jointly by the construction commission, planning commission, fiscal and auditing bureau, and other relative departments, with the construction commission representative as the leader of this office. The other form is to employ or create an agency entrusted with the whole process, which was adopted in Guangxi Laibin B Power Project (Wang et al, 1998).

\section{Operational Maturity}

Even though the regulatory and institutional frameworks for PPPs are still underdeveloped, China has registered 1064 projects in energy, telecom, transport, water and sewerage from 1990 to 2012 according the World Bank Private Participation in Infrastructure Project Database (World Bank, 2013). An unevaluated number of PPP projects is at least 7-8000 from the perspective of Dayue Consultant, which is a professional PPP consultant in China participating in more than 500 PPP projects (National Business Daily, 2014). The mismatch between the phenomenal experience wealth and the underdeveloped regulatory and institutional frameworks is driven by the high rates of economic growth and ambitious government plans for infrastructural development (EIU, 2012). As a result, China has scored the highest in this component.

PPP projects are currently handled in a similar fashion to state infrastructure projects, in which government officials do have rich experience developed from their exposure to China's huge infrastructure market. The government is also keen to employ consultants to conduct project financing, risk evaluation, bidding and contract negotiation (Ke et al., 2009). In addition, methods and criteria for PPP procurement are usually the primary focus of current PPP regulations in China. Factors such as price, technical and financial status, credit standing, services, performance, and the response to the bid-invitation documents are commonly taken into account when selecting a private partner.

Although there is yet no official guidance on risk allocation in place, risk allocations have been basically fair between the public and private sectors, because of the rich past experience (Ke et al., 2012; 2013). In addition, the Ministry of Housing and Urban-Rural Development has issued several contract samples for PPP, which 
strongly reinforce the importance of performance bonds for bidding, construction and operation. In particular on the issue of post-bid opportunism, it is typically well prevented by the limitation clauses on project interest transfer or price adjustment.

However, disputes are common because of changes in various risks or non-performance of obligations, especially when one sector is imposed to accept the requirements by the other as a result of the unequal status, the project urgency or other reasons (Ke et al., 2009). One of the common reasons is that the new officials reject to perform the obligations agreed by their predecessors when there were some changes of the head officials who are in charge of the project (Sachs et al., 2007).

\section{Investment Climate}

According to EIU (2013), the real GDP growth will average $6.7 \%$ a year in 2014-18, with economic expansion decelerating gradually over the period. Continued strong growth and high infrastructural demands have created a favorable environment for private investment via PPPs. In addition, the central government has a highly proactive attitude towards the adoption of private investment in infrastructure development, as evident from the before-mentioned statement by Premier Keqiang Li on the executive meeting of the State Council on July 312013.

There are no restraints on foreign investment in infrastructure projects, or any rules of guidelines that suggest a preference for companies with local capital or foreign investors in general. However, closer relationships between state-owned or state-holding enterprises and the government may reflect a greater capability to undertake country-level political and legal risks. In fact, state-owned or state-holding enterprises now have the major market share of PPPs (Ke et al., 2009; Wang et al., 2012).
The lure of a sizable market and a reasonable operating environment has resulted in a significant level of PPP application in China. The attractiveness of China's investment proposition would continue to be critical. However, PPP projects in China come with no guarantee of sustainability because of weak regulatory frameworks and underdeveloped institutions for PPP (EIU, 2012). Weak government effectiveness remains a threat to fostering sustainable and efficient PPP infrastructure projects. Therefore, China only scored 51.6 out of 100 in the component of investment climate.

\section{Financial Facilities}

China obtained 66.7 in the financial facilities. Responsibility for the implementation of infrastructure projects resides primarily with subnational governments. They have insufficient capacity to levy taxes and thereby make extensive use of off-budget financing options for infrastructure. The majority of subnational government debt financing is estimated to be financed by bank loans, while the majority of these loans are provided by the state-owned banks. Subnational governments have also been increasing their use of bonds in recent years. Six local governments (Shandong, Jiangsu, Guangdong, Shanghai, Shenzhen and Zhejiang) now have direct access to bond market finance under pilot schemes (Chong and Poole, 2013).

In most PPP projects, private partners have the sole responsibility for the financing component, although they may receive support in the forms of government capital grants, loans from development banks and credit enhancement. Governments have also used other methods to encourage private participation in PPPs. For instance, governments can use mechanisms to shield private parties from some of the downside risk in the form of take-orpay agreement. In certain cases, the government can provide subsidies to improve access for the poor, using two methods. The first way is to subsidize investors directly. Taking the Subway Line 4 in Beijing for example, in order to keep the service price affordable for the poor, the government introduced a subsidy mechanism based on shadow pricing (Ke et al., 2009). The second approach is to subsidize the low-income users by using differential pricing structures. For example, in order to encourage private investment in the social welfare, the governments are willing to provide compensations for low-income elderly people in bead house projects.

Debt constitutes a large proportion of PPP infrastructure financing, which may depend on the stability and predictability of cash flows. In China, debt financing in a PPP is still made up of loans from banks, because the syndicated loan market is not prevalent as a source of debt finance (Kwok, 2001), the corporate bond market is not sufficiently mature compared with sovereign bonds (Yuen, 2004), and the arrangement of floating charge on project assets as a guarantee needed for innovative project financing is not well established legally (Li, 2005).

\section{Subnational Adjustment Factor}

In China, subnational governments are empowered to develop infrastructure assets through PPP at the subnational level. China has a provincial- and citydriven PPP program operating under national regulation, but public capacity varies significantly across the provinces and cities (EIU, 2012). Therefore, China obtained 75 out of 100 in this component.

The central government is responsible for the regulatory framework and approval of all major infrastructure projects. Subnational governments provide the detailed administrative measures and take the lead role in PPP implementation. For example, measures for PPP implementation and bidding procedures issued by 
subnational governments include more detailed evaluation criteria. These measures on PPP are based on the regulations issued by the central government; therefore differences are few in essence among these subnational frameworks.

Only a few municipal governments like Chengdu and Kunming proposed to form a PPP-specific commission. Municipal Development \& Reform Commission on behalf of the subnational government usually takes the lead role in a PPP project. However, it is worth noting that the public capabilities in different cities may vary. Those more developed cities like Beijing, Shanghai, Guangdong, or Zhejiang are believed to be much more capable than less developed cities (Wang et al., 2012).

\section{Usage of PPP}

PPP modality was first introduced in the Shajiao B power plant, and furthered by subnational governments in mid 1980s. Later after 1996, several state-approved pilot BOT projects were awarded in order to promote BOT on a larger scale, such as the Laibin B power project and Chengdu No. 6 water project etc. Thereafter, the involvement of private investors in infrastructure development grew rapidly. Although at the end of 1990s, coping with the adverse effects of the Asia financial crisis, the central government invested huge amount of treasury bonds in infrastructure, which meant subnational governments could access funding more easily and did not have to depend on private investment. Also, during this stage the central government was determined to clean up the unregulated or illegal projects. This led to a fading out of the first round of private investment boom (Shen et al, 2005). However, stepping into the 21st century, the bottleneck effect of infrastructure shortage for the economic growth emerged again and imposed great budgetary pressure on the subnational governments. As a result of that, the second boom of private investment began.

The highest openness has been seen in toll road and municipal utilities including water, power, environment, city gas, etc. Subnational governments undertake the investment responsibility of those sectors with the highest openness, while the central government is responsible for pivotal railway and other special sectors. Subnational governments are keener to promote PPP implementations than the central government.

There are three main players in the PPP market, i.e. foreign enterprises, state-owned enterprises and domestic private enterprises. Foreign investors acting as the major player in the first boom usually charge higher and prefer projects in more developed regions. They may be the most efficient in operation and management, but is the least familiar with the Chinese culture. State-owned enterprises as the principle player in the second boom have relative low operation and management efficiency, which largely restrains the advantages of PPP model (Ke et al., 2009). State-owned enterprises have the strongest relationship with the government and the strongest capability to undertake country level risks. The third group of PPP players in China is the domestic private enterprises. In recent years, the involvement of these enterprises has significantly increased. Currently, state-owned enterprises and state-holding enterprises have the highest PPP market share in most infrastructure sectors. Domestic private enterprises and foreign investors are active in sectors such as water, city gas, toll road, etc., which promise considerable revenue generation.

\section{Where to from Here}

The transfer of power to a new generation of Chinese political leaders, which was completed in March 2013, is not expected to lead to any substantive change in regards to private investment in infrastructure development. This is evident from "Opinions of the State Council on Strengthening Urban Infrastructure Construction" on 6 September 2013, "Guidance for Government Purchases of Public Services from Social Organizations" by State Council General Office on 26 September 2013, and "Regulations on Urban Drainage and Sewage Treatment" by State Council on 2 October 2013. These newly issued regulations show the ongoing positive attitude of the central government. It is therefore expected to see more private involvement in infrastructure development in China via PPP mode. However, implications may be slightly different in different sectors.

In the water sector, sewage treatment and water supply projects are different in their financial self-liquidating ratio. The total cost of a sewage treatment plant cannot be covered by the wastewater tariff collected, but the tariff of water supply usually would be able to offer an appreciable return to the investors. Therefore, most water supply plants in China adopt the mode of so-called "Plant-pipeline bundle", which means the water companies collect tariff from end-users. Subnational governments would procure sewage treatment plants by means of BOT or Transfer-Operate-Transfer, and leave wastewater pipeline network to be invested and operated by government itself. Sewage treatment companies usually collect fee from subnational governments according to their treatment volume. The "Regulations on Urban Drainage and Sewage Treatment" issued by State Council on 2 October 2013 will standardize and promote the private investment in the sewage treatment sector.

BOT is the most popular model in toll roads, where private investors directly collect tariff from passengers. Under this arrangement, private operators of toll roads undertake the risk of traffic 
flow volume and consequent risk of toll revenue. Because provincial authority of road transportation regulates the tariff, toll road companies usually fail to adjust the tariff based on the operation cost according to the concession agreement (Zhang, 2009). The analysis on the operational maturity and subnational adjustment factor could indicate that the frequent usage of PPP in toll roads will continue in the future.

In the rail transportation sector, the most critical issues are the lower project financial self-liquidating ratio and unclear subsidiary and profit mechanisms. These critical issues make it much more difficult for private participation (except in some dedicated lines with independent tariff settlement). The railway sector thus has the least openness to the private. The same issue has been seen in the urban railway development. Hugh investment requirement and the low fare to accommodate public welfare concerns greatly reduce the possibility for private investors to obtain reasonable financial return during operation. Further, under current Chinese land law it is not allowed for subnational governments to grant the land in surrounding areas of stations to the investors without competitive tendering. Subsequently, the integration between land use and transportation development cannot be achieved. Allowing the use of land by the investors around stations can not only support a higher intensity of urban activities which can provide better value for money, but also, investors can implement more innovative approaches that allows them to generate more revenue which can compensate the high construction costs. As mentioned in the legal and regulatory framework section, private investments are welcomed in railway and urban subway sectors. However, it is expected for the government to be responsible for part of the construction, or to provide a subsidy during the operation period.
The revenue of a PPP gas project comprises the connection charge and commodity charge, where the connection charge is applicable when a user accesses to the pipeline network, and the commodity charge means the tariff on the amount of gas throughput on the transmission network. Given the lack of governmental fiscal support to the construction of pipeline networks, it may be reasonable and necessary to charge for connection. The main player in the construction of networks is still and will continue to be state owned enterprises. As explained in the section "Usage of PPP" that state-owned enterprises have the strongest relationship with the government and the strongest capability to undertake projects with issues of complicated tariff mechanisms.

As emphasized in China's 12th FiveYear Plan, upgrading social welfare and increasing urbanization rate are key initiatives. Thereafter, a national debate of PPP usage in urban comprehensive development, urbanization, bead house, low-income housing, etc. has been seen. In addition, there are limited PPP projects in the education, health, security and other social sectors. An increase of PPP application in these sectors could be expected in the near future.

Another change is seen in the national contemplation whether PPP is a panacea for infrastructure development. China's demand for more public infrastructure and services has imposed great pressure on the government's budget. This hence causes the subnational governments' favor of using PPP without carefully considerations on feasibility of PPP. But the central government has realized this issue and proposed a draft of "Guidance for Concession Evaluation of Municipal Public Utilities". The draft proposed a four-step investment evaluation process, i.e. 1) whether is the project worthwhile; 2 ) should it be done using traditional public procurement or
PPP; and 3) if using PPP, which specific model should be adopted; 4) if using a specific model, which aspects should be and how to be evaluated and performance monitored.

\section{Conclusion}

With the continual economic growth in China, the increasing need of infrastructures has been placing budgetary pressure on the government. Private investors cannot afford to ignore the scale of the infrastructure market in China. The private sector's eagerness to invest in this market and the public sector's need for private investment and higher efficiency will ensure appropriate solutions for PPPs to work. This paper reviewed the PPP application in China. It was found that China has a wealth of experience with PPPs, and the number of PPP projects will continue to rise in the future. However, its underdeveloped institutional framework and regulatory environment provide no guarantee of sustainability for PPP projects. Investors should align their interests with the public sector and hence obtain the support from subnational governments, especially for projects with a weak revenue generating capability.

\section{References}

\footnotetext{
Chan, A.P.C., Lam, P.T.I., Chan, D.W.M., Cheung, E. and Ke, Y. (2009). “Drivers for Adopting Public Private Partnerships - Empirical Comparison between China and Hong Kong Special Administrative Region." Journal of Construction Engineering and Management, 135(11), 1115-1124.

Chan, A.P.C., Lam, P.T.I., Chan, D.W.M., Cheung, E. and Ke, Y. (2010). “Potential Obstacles to Successful Implementation of Public-Private Partnerships in Beijing and the Hong Kong Special Administrative Region." Journal of Management in Engineering, 26(1), 30-40.

Chong, S. and Poole, E. (2013). "Financing Infrastructure: A Spectrum of Country Approaches.” Bulletin, September Quarter 2013, Reserve Bank of Australia, 65-76.
}

Economist Intelligence Unit (2012). Evaluating 
the environment for public-private partnerships in Asia-Pacific: The 2011 Infrascope, Asian Development Bank, May 2012.

Economist Intelligence Unit (2013) "My EIU > Country > China > Summary: At a glance." http://country.eiu.com/article.aspx?articleid $=1721071756 \&$ Country $=$ China\&topic $=$ Summa ry\&subtopic $=A t+a+$ glance $>($ Feb. 13, 2014).

Ke, Y., Wang, S.Q. and Chan, A.P.C. (2009). “Public-Private Partnerships in China's Infrastructure Development: Lessons Learnt.” Proceedings of Changing roles: new roles, new challenges (CIB Wo96, W104), Noordwijk ann Zee, Netherlands, October 5-9, 2009, 177-188.

Ke, Y., Wang, S., and Chan, A. P. C. (2012). "Risk management practice in China's PublicPrivate Partnership projects.” Journal of Civil Engineering and Management, 18(5), 675-684.

Ke, Y., Wang, S.Q. and Chan, A.P.C. (2013). “Risk Misallocation in Public-Private Partnership Projects in China." International Public Management Journal, 16(3), 438-460.

Kwok, H.C. (2001). Legal Issues of International Syndicated Loan, The Legal Publisher (in Chinese)

Li, A. (2005). Innovation Guarantees in International Financing, Beijing University Press (in Chinese)

National Audit Office (2013) Audit results of government debts. No. 32 of $\mathbf{2 0 1 3}$, General Serial No. 174 , China.

National Business Daily (2014) “Interview with PPP expert Mr Yongxiang Jin: spirit of contract is required when promoting PPP (in Chinese)". http://www.nbd.com.cn/ articles/2014-03-21/819119.html>(Jul. 22, 2014)

National Council for Public-Private Partnerships (2013). "7 Keys to Success." http://www. ncppp.org/ppp-basics/7-keys>(Feb. 13, 2014).

Sachs, T., Tiong, R.L.K. and Wang, S.Q. (2007). “Analysis of Political Risks and Opportunities in Public Private Partnerships in China and Selected Asian Countries - Survey Results." Chinese Management Studies, 1(2), 126-148.

Shen JY, Wang SQ and Qiang MS (2005). "Political risks and Sovereign Risks in Chinese BOT/PPP projects: A Case Study (in Chinese)." Chinese Businessman Investment and Finance, (1), 50-55.
Wang, S.Q., Ke, Y. and Xie, J. (2012). “PublicPrivate Partnership Implementation in China." in G.M. Winch, M. Onishi and S. Schmidt (ed.), Taking Stock of PPP and PFI Around the World, ACCA, London: Certified Accountants Educational Trust, Feb 2012, p.p. 29-36.

Wang, S.Q., Tiong, R.L.K., Ting, S., Chew, D., and Ashley, D. (1998). "Evaluation and Competitive Tendering of BOT Power Plant Project in China." Journal of Construction and Engineering Management, 124(4), 333-341.

World Bank (2013). “Country Snapshots China.” http://ppi.worldbank.org/explore/ ppi_exploreCountry.aspx?countryID=50>(Feb. 13, 2014).

Yuen, T. (2004). Analysis of Secondary Bond Market in China: Comparison between Exchange Market and Interbank Market, Economic Science Press (in Chinese)

Zhang L (2009). “Development of infrastructure sectors in China: status quo and trends." Revamping PPPs: From 'Revisiting and Rethinking' to 'Revamping and Revitalising' PPPs, The University of Hong Kong, Hong Kong, China, February 28. 